\title{
慢性透析導入患者の臨床的検討
}

\author{
大矢晃宮形滋加藤隆三 \\ 原 田忠土田 正 義 \\ 秋田大学泌尿器科
}

(昭和 61 年 12 月 22 日受付)

key words : chronic renal failure, initiation of regular dialysis, prognosis

〈要旨〉

昭和 45 年 11 月より昭和 60 年 12 月までに慢性透析に導入した患者 148 名について透析導入時を中心として臨床統 計観察を行った.

148 名中男性は 93 名, 女性は 55 名で, 男女比は $1.69: 1$ であった. 年齢は 14 歳から 78 歳で, 平均年齢は 48.4 歳 であった。

原疾患は慢性糸球体腎炎が 64 名と一番多く，つづいて糖尿病の 21 名であったが, 原疾患が不明な患者も 22 名に達 していた.

透析導入時の主訴については, 倦总感と疲労感が $48.0 \%$ と最も多かった。臨床検査成績では導入時, 心胸比 $53.5 \pm$ $8.2 \%, B U N 111 \pm 36 \mathrm{mg} / \mathrm{d} l, \mathrm{Cr} 11.6 \pm 4.9 \mathrm{mg} / \mathrm{d} l$ であった。

昭和 61 年 1 月 1 日現在, 148 名中 55 名が死亡しており, 死因の第一位は心不全 19 名, 第二位は脳血管障害 12 名で あった。透析導入後の実測生存率についてみると， 5 年生存率 $56.7 \%, 10$ 年生存率 $46.1 \%$ あっった.

\section{Clinical aspects of chronic renal failure at the initiation of regular dialysis treatment}

Akira Oya, M. D., Shigeru Miyagata, M. D., Ryuuzou Kato, M. D., Tadashi Harada M. D., and Seigi Tsuchida M. D.*

Department of Urology (Director : Prof. S. Tsuchida), Akita University School of Medicine, ${ }^{*}$ Akita, Japan

A clinical survey was performed on 148 cases of chronic renal failure at our hospital from November 1970 to December 1985.

There were 93 males and 55 females, the ratio of males to females was $1.69: 1$ and patients ranged in age from 14 to 78 years, with an average of 48.4 years old.

In terms of primary renal disease, 64 of 148 had chronic glomerulonephritis, 21 diabetic nephropathy and 22 unknown disease.

The most frequent symptom was easy fatigability and general fatigue $(48.0 \%)$. BUN and $\mathrm{Cr}$ levels at the beginning of dialysis were $111 \pm 36 \mathrm{mg} / \mathrm{d} l$ and $11.6 \pm 4.9 \mathrm{mg} / \mathrm{d} l$ respectively.

Actual. 5 and 10 -year survival rates for all patients were $56.7 \%$ and $46.1 \%$, respectively. The main causes of death in dialysis patients were cardiovascular disease (19 cases) and cerebrovascular disease (12 cases).

\section{緒言}

秋田大学医学部泌尿器科では昭和 45 年 4 月に透析セ ンターを開設し，透析療法を開始した。それに伴い昭和 45 年 11 月より慢性腎不全患者を慢性透析に導入し始 め, 以来約 15 年が経過した。

\section{大矢 晃 秋田大学泌尿器科}

于 010 秋田市本道 1-1-1 (0188-34-1111)
現在では透析療法の進歩に伴い透析への導入が円滑に 行われ，また透析導入の適応も以前より拡大され，いわ ゆる系統的疾患（特に糖尿病）も透析導入の対象となり， 原疾患の状態が透析患者の予後を決定する重要な因子と なっている1

そこで今回我々は過去 15 年間に慢性透析に導入した 患者 148 名について透析導入時を中心としていろいろな 
表 1 性別および年齢

\begin{tabular}{c|r|r|r}
\hline 年 齢 & 男 & 女 & 総 \\
\hline $0-9$ & 0 & 0 & 0 \\
$10-19$ & 3 & 2 & 5 \\
$20-29$ & 13 & 10 & 23 \\
$30-39$ & 12 & 10 & 22 \\
$40-49$ & 13 & 6 & 19 \\
$50-59$ & 21 & 13 & 34 \\
$60-69$ & 20 & 8 & 28 \\
$70-79$ & 11 & 6 & 17 \\
$80-$ & 0 & 0 & 0 \\
\hline 総 計 & 93 & 55 & 148 \\
\hline
\end{tabular}

表 2 慢性透析患者の原疾患

\begin{tabular}{lr|r|r|r}
\hline \multicolumn{2}{c|}{ 疾 患 名 } & 男 & 女 & 総 \\
\hline 慢性 系球 体 \\
腎 炎
\end{tabular}

観点から臨床的な分析を試み，予後についても調査した ので報告する。

\section{対象および方法}

昭和 45 年 11 月より昭和 60 年 12 月までに秋田大学医 学部泌尿器科透析センターで慢性透析に導入した患者 148 名を対象とした。

各症例について性別, 導入時年齢, 主訴, 原疾患, 入 院・導入・退院・死亡年月日, 死亡原因，導入時ブラッ ド・アクセス, 導入前後の臨床検査データー等を調查し, 必要に応じて全症例, 生存退院例, 死亡退院例, 非糖尿 病例，糖尿病例に分けて検討した。

\section{結果}

1. 性別抒よび年齢（表 1)

148 名中男性は 93 名, 女性は 55 名, 男女比は 1.69 ： 1.00 であり，男性が多かった。

導入時年齢は 14 歳から 78 歳で平均年齢は $48.4 \pm$
表 3 月・年別導入患者数

\begin{tabular}{c|cccccccccccc|c}
\hline $\begin{array}{c}\text { 月 } \\
\text { 年 }\end{array}$ & 1 & 2 & 3 & 4 & 5 & 6 & 7 & 8 & 9 & 10 & 11 & 12 & 総計 \\
\hline 45 & & & & & & & & & & & 1 & & 1 \\
46 & & & & & & 3 & & & & & & \\
47 & & & & & & & 2 & 1 & 1 & 1 & & & 5 \\
48 & 1 & & 1 & & & 1 & & 1 & & & & 3 & 7 \\
49 & & & & & & 1 & & & & & & & 1 \\
50 & & & & 1 & 1 & 1 & & & 1 & 2 & & 1 & 7 \\
51 & & 1 & & & & 1 & & 2 & & & 1 & & 5 \\
52 & 1 & 1 & 1 & 1 & & & 1 & 1 & 1 & & 1 & 2 & 10 \\
53 & & & 2 & & 1 & 1 & & & 2 & 1 & & & 7 \\
54 & 3 & 2 & 1 & & & & 1 & 1 & 1 & & 1 & & 10 \\
55 & 1 & & & 2 & 1 & 1 & 2 & 1 & & 4 & & & 12 \\
56 & 1 & 2 & 1 & 2 & & 2 & & & & 1 & 1 & 3 & 13 \\
57 & & 1 & & 2 & 2 & 1 & 1 & 3 & 2 & 1 & 1 & 1 & 15 \\
58 & 2 & 1 & & 2 & 1 & 1 & 4 & & & 4 & & 4 & 19 \\
59 & 4 & 3 & 3 & 3 & & & & 1 & & & 1 & 1 & 16 \\
60 & 4 & 2 & & & 2 & 2 & 2 & & & 1 & & 4 & 17 \\
\hline 総計 & 17 & 13 & 9 & 13 & 8 & 15 & 13 & 11 & 8 & 15 & 7 & 19 & 148 \\
\hline
\end{tabular}

表 4 導入時の主訴

\begin{tabular}{|c|c|c|c|c|c|}
\hline 症 & $\begin{array}{l}\text { 全症例 } \\
\text { (148) }\end{array}$ & $\begin{array}{c}\text { 死亡例 } \\
\text { (55) }\end{array}$ & $\begin{array}{c}\text { 死亡退院 } \\
(18)\end{array}$ & $\begin{array}{c}\text { 非糖尿病 } \\
(127)\end{array}$ & $\begin{array}{l}\text { 糖尿病 } \\
(21)\end{array}$ \\
\hline 倦怠感・疲労感 & $48.0 \%$ & $45.5 \%$ & $50.0 \%$ & $49.6 \%$ & $38.1 \%$ \\
\hline 嘔気・嘔吐 & 16.9 & 27.3 & 33.3 & 15.7 & 23.8 \\
\hline 食欲不振 & 14.2 & 18.2 & 22.2 & 12.6 & 23.8 \\
\hline 呼吸困難 & 23.6 & 20.0 & 22.2 & 22.0 & 33.3 \\
\hline 晐・痰 & 9.5 & 10.9 & 16.7 & 8.7 & 14.3 \\
\hline 浮腫 & 35.8 & 32.7 & 38.9 & 37.0 & 47.6 \\
\hline 泛尿 & 6.8 & 1.8 & 5.6 & 5.5 & 14.3 \\
\hline 頭痛 & 6.8 & 5.5 & 5.6 & 7.9 & 0 \\
\hline 視力障害 & 5.4 & 1.8 & 5.6 & 2.4 & 9.5 \\
\hline 眩軍 & 2.0 & 1.8 & 5.6 & 2.4 & 0 \\
\hline その他 & 34.5 & 45.5 & 55.6 & 33.8 & 38.1 \\
\hline 不明 & 2.0 & 3.6 & 5.6 & 1.6 & 4.8 \\
\hline
\end{tabular}

16.8 歳（平均士標準偏差）であり，50 歳台が 34 名と最 も多数を占め, ついで 60 歳台の 28 名であった。

2. 慢性透析導入患者の原疾患（表 2 ）

原疾患としては慢性系球体腎炎が 64 名 (43.2\%) と一 番多く，続いて糖尿病が 21 名 (14.2\%)，ネフローゼ症 候群と多発性囊胞腎が各 8 名 (5.4\%) の順番であった. しかし原疾患が不明な患者は 22 名にも達していた。

3 . 月・年別導入患者数 (表 3 )

月別では 12 月が 19 名 (12.8\%) と最も多く, つぎに 1月の 17 名 (11.5\%) であり，季別に分けてみると冬季 にあたる 12〜2月が 49 名 (33.1\%) と最も多く, 続いて 夏期にあたる 6 ～8 月が 39 名 (26.4\%) であった．年別 では昭和 45 年の当科透析センター開設以来毎年ほぼ順 
表 5 臨床検查成績

\begin{tabular}{|c|c|c|c|c|c|}
\hline 検査項態 & 全 体 & 生存退院 & 死亡退院 & 非糖尿病 & 䌅尿病 \\
\hline 年齢 & $48.4 \pm 16$ & $47.4 \pm 16.9$ & $56.0 \pm 14$ & $46.4 \pm 17.0$ & $60.9 \pm 8.9$ \\
\hline 入院日数 & $159 \pm 249$ & $163 \pm 259$ & $131 \pm 161$ & $165 \pm 265$ & $118 \pm 91$ \\
\hline 導入日数 & $17 \pm 33$ & $17 \pm 33$ & $24 \pm 31$ & $18 \pm 35$ & $12 \pm 17$ \\
\hline シャント作製- & & & & & \\
\hline 導入日数 & $25 \pm 107$ & $24 \pm 105$ & $38 \pm 125$ & $20 \pm 67$ & $58 \pm 239$ \\
\hline 導入- & & & & & \\
\hline 退院日数 & $132 \pm 210$ & $135 \pm 215$ & $108 \pm 164$ & $136 \pm 223$ & $107 \pm 91$ \\
\hline 入院時体重（kg） & $55.7 \pm 10$ & $55.8 \pm 10.1$ & $55.0 \pm 9.8$ & $55.1 \pm 10.1$ & $59.5 \pm 8.6$ \\
\hline 導入時体重（kg） & $54.8 \pm 9.8$ & $54.8 \pm 9.8$ & $54.5 \pm 9.7$ & $54.1 \pm 9.6$ & $59.2 \pm 9.7$ \\
\hline 標準体重 (kg) & $51.0 \pm 8.7$ & $51.1 \pm 8.8$ & $50.5 \pm 8.5$ & $50.6 \pm 8.8$ & $53.6 \pm 8.0$ \\
\hline $\begin{array}{r}\text { 透析時間 }(\mathrm{hr} / \mathrm{w}) \\
\text { <導入時検査> }\end{array}$ & $14.1 \pm 3.8$ & $14.0 \pm 3.8$ & $14.9 \pm 4.2$ & $14.0 \pm 3.8$ & $15.2 \pm 3.6$ \\
\hline 収縮期血圧 (mmHg) & $151 \pm 31$ & $151 \pm 29$ & $155 \pm 41$ & $150 \pm 31$ & $162 \pm 26$ \\
\hline 拡張期血圧 (mmHg) & $87 \pm 23$ & $87 \pm 24$ & $84 \pm 18$ & $88 \pm 24$ & $80 \pm 14$ \\
\hline 尿量 $(\mathrm{m} l /$ day $)$ & $984 \pm 627$ & $981 \pm 623$ & $1009 \pm 671$ & $976 \pm 638$ & $1036 \pm 560$ \\
\hline 心胸比（\%） & $53.5 \pm 8.2$ & $53.5 \pm 8.3$ & $53.7 \pm 7.9$ & $53.2 \pm 8.3$ & $55.6 \pm 7.4$ \\
\hline 赤血球数（万） & $256 \pm 65$ & $254 \pm 63$ & $274 \pm 81$ & $256 \pm 65$ & $258 \pm 67$ \\
\hline $\mathrm{Ht}(\%)$ & $22.8 \pm 5.6$ & $22.6 \pm 5.4$ & $24.9 \pm 7.1$ & $22.8 \pm 5.6$ & $23.0 \pm 5.7$ \\
\hline 血小板数 (万) & $19.5 \pm 8.1$ & $19.7 \pm 8.3$ & $17.7 \pm 6.5$ & $19.2 \pm 8.2$ & $20.9 \pm 7.4$ \\
\hline $\mathrm{TP}(\mathrm{g} / \mathrm{d} l)$ & $6.1 \pm 1.0$ & $6.2 \pm 0.9$ & $5.9 \pm 1.2$ & $6.2 \pm 0.9$ & $5.8 \pm 1.1$ \\
\hline $\mathrm{BUN}(\mathrm{mg} / \mathrm{d} l)$ & $111 \pm 36$ & $112 \pm 35$ & $104 \pm 38$ & $114 \pm 35$ & $94 \pm 38$ \\
\hline $\mathrm{UA}(\mathrm{mg} / \mathrm{d} l)$ & $9.3 \pm 3.2$ & $9.1 \pm 3.1$ & $10.3 \pm 3.8$ & $9.5 \pm 3.3$ & $8.2 \pm 2.7$ \\
\hline $\mathrm{Cr}(\mathrm{mg} / \mathrm{d} l)$ & $11.6 \pm 4.9$ & $11.8 \pm 4.9$ & $9.9 \pm 4.7$ & $12.1 \pm 4.9$ & $8.8 \pm 3.6$ \\
\hline $\mathrm{Na}(\mathrm{mEq} / l)$ & $137 \pm 6$ & $137 \pm 5$ & $132 \pm 11$ & $137 \pm 5$ & $136 \pm 10$ \\
\hline $\mathrm{K}(\mathrm{mEq} / l)$ & $4.4 \pm 1.1$ & $4.3 \pm 1.0$ & $4.7 \pm 1.2$ & $4.4 \pm 1.1$ & $4.2 \pm 1.0$ \\
\hline $\mathrm{Ca}(\mathrm{mg} / \mathrm{d} l)$ & $7.8 \pm 1.2$ & $7.8 \pm 1.1$ & $8.1 \pm 2.1$ & $7.8 \pm 1.1$ & $8.1 \pm 1.7$ \\
\hline $\begin{array}{l}\mathrm{P}(\mathrm{mg} / \mathrm{d} l) \\
\quad<\text { 退院時検查> }\end{array}$ & $7.1 \pm 2.7$ & $6.2 \pm 0.9$ & $6.5 \pm 3.0$ & $7.5 \pm 2.7$ & $5.3 \pm 1.9$ \\
\hline 収縮期血圧（mmHg） & $137 \pm 25$ & $136 \pm 24$ & $146 \pm 34$ & $136 \pm 25$ & $144 \pm 27$ \\
\hline 拡張期血圧（mmHg） & $81 \pm 17$ & $80 \pm 16$ & $85 \pm 22$ & $82 \pm 17$ & $75 \pm 16$ \\
\hline 尿量 (ml/day) & $515 \pm 500$ & $524 \pm 490$ & $449 \pm 576$ & $507 \pm 492$ & $561 \pm 555$ \\
\hline 心胸比（\%） & $50.1 \pm 6.3$ & $49.5 \pm 6.0$ & $55.4 \pm 6.1$ & $49.7 \pm 6.3$ & $52.4 \pm 5.4$ \\
\hline 赤血球数（万） & $253 \pm 56$ & $252 \pm 52$ & $256 \pm 81$ & $252 \pm 58$ & $256 \pm 44$ \\
\hline Ht (\%) & $22.9 \pm 5.0$ & $22.8 \pm 4.6$ & $23.5 \pm 7.3$ & $22.9 \pm 5.2$ & $23.0 \pm 3.3$ \\
\hline 血小板数（万） & $21.9 \pm 9.0$ & $22.6 \pm 8.8$ & $16.0 \pm 8.4$ & $21.8 \pm 8.8$ & $22.6 \pm 9.9$ \\
\hline $\mathrm{TP}(\mathrm{g} / \mathrm{d} l)$ & $6.6 \pm 0.8$ & $6.8 \pm 0.6$ & $5.6 \pm 1.1$ & $6.7 \pm 0.7$ & $6.3 \pm 0.8$ \\
\hline $\mathrm{BUN}(\mathrm{mg} / \mathrm{d} l)$ & $75 \pm 27$ & $73 \pm 22$ & $93 \pm 48$ & $76 \pm 26$ & $70 \pm 31$ \\
\hline $\mathrm{UA}(\mathrm{mg} / \mathrm{d} l)$ & $8.2 \pm 2.6$ & $8.1 \pm 1.9$ & $9.3 \pm 5.5$ & $8.2 \pm 2.0$ & $8.2 \pm 5.2$ \\
\hline $\mathrm{Cr}(\mathrm{mg} / \mathrm{d} l)$ & $9.5 \pm 3.1$ & $9.8 \pm 3.0$ & $7.6 \pm 3.1$ & $10.0 \pm 3.0$ & $7.1 \pm 1.9$ \\
\hline $\mathrm{Na}(\mathrm{mEq} / l)$ & $138 \pm 5$ & $138 \pm 4$ & $135 \pm 6$ & $138 \pm 5$ & $136 \pm 6$ \\
\hline $\mathrm{K}(\mathrm{mEq} / l)$ & $4.5 \pm 1.0$ & $4.5 \pm 1.0$ & $4.4 \pm 1.1$ & $4.6 \pm 1.0$ & $4.1 \pm 0.9$ \\
\hline $\mathrm{Ca}(\mathrm{mg} / \mathrm{d} l)$ & $8.7 \pm 1.1$ & $8.7 \pm 1.0$ & $8.9 \pm 2.1$ & $8.7 \pm 1.0$ & $8.9 \pm 1.8$ \\
\hline $\mathrm{P}(\mathrm{mg} / \mathrm{d} l)$ & $5.4 \pm 2.1$ & $5.5 \pm 2.1$ & $3.3 \pm 0.8$ & $5.5 \pm 2.1$ & $4.2 \pm 1.5$ \\
\hline 総 & 148 名 & 130 名 & 18 名 & 127 名 & 21 名 \\
\hline
\end{tabular}

調に増加してきたが，ここ数年は関連施設での透析導入 が増加しているため横ばいとなっている。

4. 導入時の主訴 (表 4 )

全症例を対象として主訴を積算してみると，倦急感・ 疲労感が $48.0 \%$ に認められ，ついで浮腫 $35.8 \%$, 呼吸困 難 $23.6 \%$ の順番であり, 嘔気・嘔吐, 食欲不振等の消化
器症状は少なかった。原疾患が糖尿病（糖疗病性腎症） の患者では浮腫が $47.6 \%$ と最も多く，ついで倦总感・疲 労感 $38.1 \%$, 呼吸困難 $33.3 \%$ となり低蛋白血症と関連す る症状が著明であった。 また視力障害は $9.5 \%$ あったた が, 糖尿病性網膜症や白内障はほぼ全例に認められた。

\section{5. 臨床検査成績等 (表 5 )}


表 6 導入時のブラッドアクセス

\begin{tabular}{|c|c|}
\hline 内シャント & 47 \\
\hline 大腿静脈穿刺 $\rightarrow$ 内シント & 33 \\
\hline 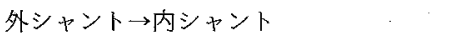 & 20 \\
\hline 腹膜灌流 $\rightarrow$ 内シャント & 12 \\
\hline 外シャント & 8 \\
\hline 腹膜灌流 $\rightarrow$ 外シャント & 6 \\
\hline 大腿静脈穿刺 $\rightarrow$ 外シャント $\rightarrow$ 内シャント & 5 \\
\hline 動脈穿刺 $\rightarrow$ 内ャント & 3 \\
\hline CAPD & 3 \\
\hline その他 & 10 \\
\hline 不明 & 1 \\
\hline
\end{tabular}

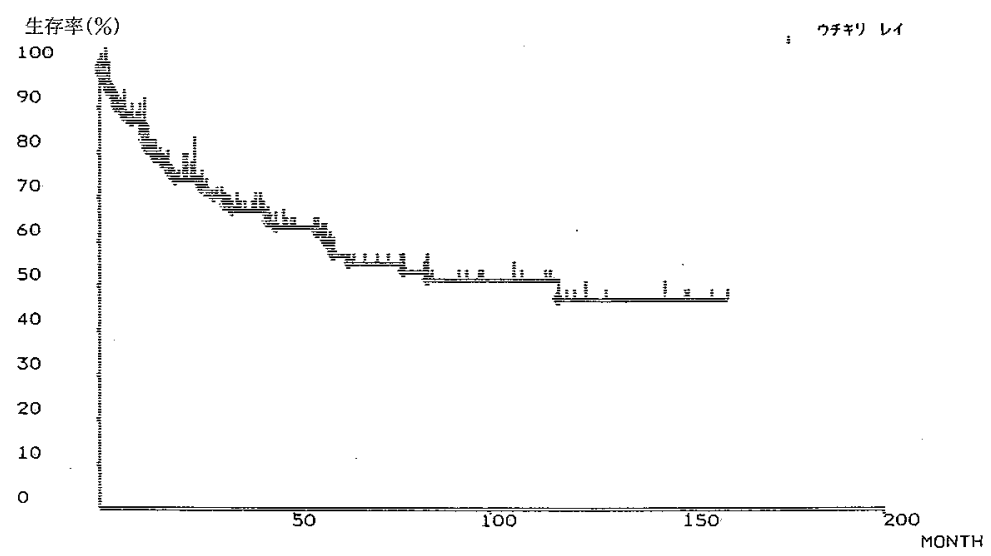

図 1 全体の生存率

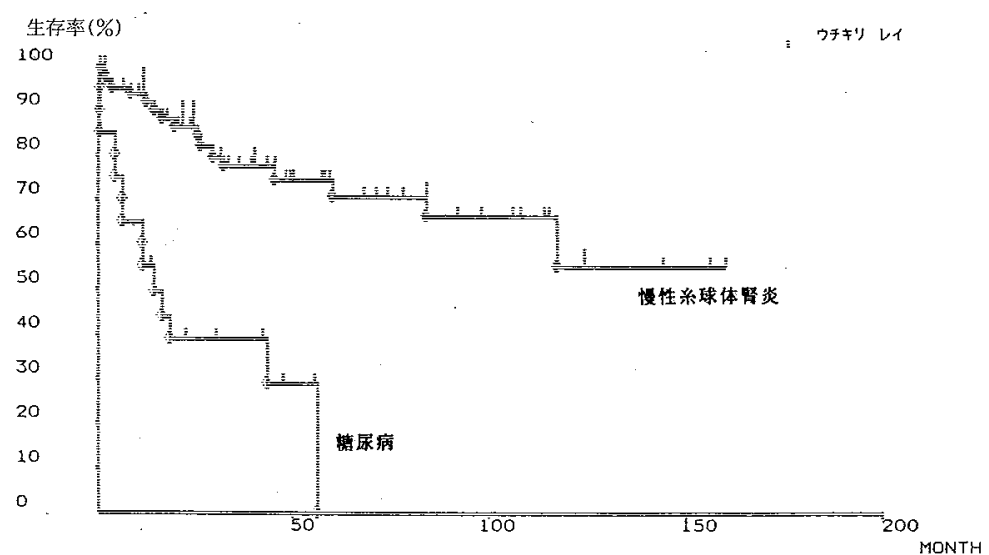

図 2 原疾患が慢性系球体腎炎と糖尿病の患者の生存率の比較

主な項目について入院時, 導入時, 導入一力月後, 退 院時（死亡退院も含む）の 4 期に分けて比較したが，そ れらの中で特に導入時と退院時の成績について検討を加 えた (平均値士標準偏差).

導入時年齢は平均 $48.4 \pm 16.8$ 歳で死亡退院例と糖尿 病例が有意に高く，おのおの $56.0 \pm 14.3$ 歳, $60.9 \pm 8.9$
表 7 入院, ブラッドアクセス作製と透析導入まで の日数

\begin{tabular}{|c|c|c|c|c|c|c|c|}
\hline & \multicolumn{5}{|c|}{ シャント作製〜透析導入 } & \multirow{2}{*}{ 総計 } \\
\hline & & 1 日 & 2〜7日 & 8〜14日 & $15 \sim 30$ 日 & 31 日〜 & \\
\hline \multirow{6}{*}{$\begin{array}{l}\text { 入 } \\
\text { 院 } \\
\text { 透 } \\
\text { 晳 } \\
\text { 導 } \\
\text { 人 }\end{array}$} & 1日 & 29 & & & 1 & & 30 \\
\hline & $2 \sim 7 日$ & 33 & 4 & 1 & & 6 & 44 \\
\hline & 8〜14 日 & 9 & 6 & 6 & & 4 & 25 \\
\hline & 15 30日 & 7 & 7 & 5 & 4 & 1 & 24 \\
\hline & 31 日～ & 9 & 2 & 1 & 10 & 2 & 24 \\
\hline & 総 計 & 87 & 19 & 13 & 15 & 13 & 147 \\
\hline
\end{tabular}


表 8 死亡症例

\begin{tabular}{|c|c|c|c|c|c|c|c|}
\hline 量 & 性 & 年䤮 & 原 疾 患 & 入院 & 導入 & 死亡 & 死因 \\
\hline 1 & 女 & 73 & 明 & $45 / 11 / 02$ & $45 / 11 / 02$ & $51 / 02 / 22$ & 脳血管障害 \\
\hline 2 & 男 & 47 & 慢性系球体腎炎 & $46 / 06 / 03$ & $46 / 06 / 17$ & $46 / 07 / 16$ & 脳血管 \\
\hline 3 & 男 & 30 & ネフローゼ症候群 & $46 / 06 / 11$ & $46 / 06 / 28$ & $47 / 12 / 03$ & 自 \\
\hline 4 & 男 & 51 & 慢性系球体腎炎 & $46 / 07 / 22$ & $46 / 08 / 16^{\circ}$ & $53 / 07 / 10$ & 心 \\
\hline 5 & 男 & 51 & 神 経 因 性 膀 胱 & $47 / 06 / 12$ & $47 / 07 / 11$ & $52 / 04 / 20$ & 不 \\
\hline 6 & 女 & 59 & 多発 性 腎 囊胞 & $47 / 07 / 10$ & $47 / 07 / 21$ & $54 / 01 / 21$ & 心 \\
\hline 7 & 男 & 52 & 多発 性 腎 囊 胞 & $47 / 08$ & $47 / 08 / 15$ & 7/18 & 肺 \\
\hline 9 & 男 & 40 & 慢性系球体腎炎 & $47 / 10$ & $47 / 10 / 31$ & $/ 20$ & 心筋 梗 塞 \\
\hline 11 & 女 & 54 & 多発性腎露胞 & $47 / 12 / 22$ & $48 / 03 / 01$ & & 脳血管障害 \\
\hline 12 & 男 & 34 & 慢性系球体腎炎 & $48 / 06 / 08$ & $48 / 06 / 08$ & & 脳血管障害 \\
\hline 14 & 男 & 46 & 慢性系球体腎炎 & $48 / 12 / 06$ & $48 / 12 / 14$ & $49 / 01 / 20$ & 心 不 全 \\
\hline 19 & 男 & 31 & 慢性系球体腎炎 & $50 / 04 / 09$ & $50 / 05 / 15$ & $52 / 06 / 06$ & 脳血管障害 \\
\hline 20 & 女 & 34 & 慢性糸球体腎炎 & $50 / 06 / 18$ & $50 / 06 / 21$ & $51 / 08 / 14$ & 心 不 全 \\
\hline 21 & 女 & 21 & 慢性系球体腎炎 & $50 / 08 / 12$ & $50 / 09 / 03$ & $51 / 08 / 15$ & 心 \\
\hline 28 & 男 & 39 & 慢性系球体腎炎 & $51 / 06 / 24$ & $51 / 08 / 18$ & $54 / 02 / 19$ & 心 \\
\hline 29 & 女 & 28 & 慢性系球体腎炎 & $51 / 11 / 04$ & $51 / 11 / 24$ & $56 / 11 / 02$ & 心 \\
\hline 33 & 男 & 60 & 糖尿病 & $52 / 03 / 03$ & $52 / 04 / 14$ & $52 / 07 / 01$ & 脳血管障害 \\
\hline 34 & 男 & 23 & 慢性系球体腎炎 & $52 / 07 / 02$ & $52 / 07 / 02$ & 54/07/19 & 肺 出 血 \\
\hline 35 & 女 & 61 & 慢性系球体腎炎 & $52 / 08 / 02$ & $52 / 08 / 31$ & $53 / 03 / 20$ & 脳血管障害 \\
\hline 36 & 女 & 51 & 慢 性 腎勐腎炎 & $52 / 08 / 09$ & $52 / 09 / 02$ & $55 / 04 / 22$ & 心 不 全 \\
\hline 39 & 男 & 48 & ネフローゼ症候群 & $52 / 12 / 20$ & $52 / 12 / 21$ & $54 / 05 / 14$ & 球 \\
\hline 40 & 女 & 30 & SLE & $53 / 03 / 01$ & $53 / 03 / 02$ & $55 / 06 / 15$ & 消化管出血 \\
\hline 43 & 男 & 59 & 多発性骨髄腫 & $53 / 06 / 08$ & $53 / 06 / 09$ & $53 / 11 / 02$ & 消化管出血 \\
\hline 44 & 女 & 36 & 慢性系球体腎炎 & $53 / 09 / 06$ & $53 / 09 / 09$ & $53 / 12 / 19$ & 心 不 全 \\
\hline 45 & 男 & 69 & 糖尿病 & $53 / 09 / 08$ & $53 / 09 / 09$ & $54 / 02 / 26$ & 気 道閉塞 \\
\hline 46 & 女 & 71 & 結 & $53 / 10 / 21$ & $53 / 10 / 21$ & $54 / 10 / 16$ & 脳血管障 害 \\
\hline 51 & 女 & 31 & & $54 / 01 / 24$ & $54 / 02 / 09$ & $54 / 12 / 17$ & 心 不 全 \\
\hline 52 & 女 & 26 & ネフローゼ症候群 & $54 / 02 / 15$ & $54 / 03 / 20$ & $54 / 04 / 02$ & 消化管出血 \\
\hline 55 & 男 & 46 & 慢性系球体腎炎 & $54 / 09 / 26$ & $54 / 09 / 29$ & $57 / 02 / 12$ & 脳血管障害 \\
\hline 58 & 男 & 61 & 糖 & $55 / 04 / 08$ & $55 / 04 / 18$ & $59 / 12 / 17$ & 心 不 全 \\
\hline 59 & 男 & 60 & 糖＼cjkstart尿 & $55 / 04 / 19$ & $55 / 04 / 19$ & $55 / 0$ & 心 \\
\hline 61 & 女 & 60 & 慢性 腎盘 腎炎 & $55 / 06 / 16$ & $55 / 06 / 28$ & $55 / 4$ & \\
\hline 62 & 男 & 73 & 不 明 & $55 / 07 / 11$ & $55 / 07 / 19$ & $56 / 02 / 23$ & 動脈瘤破裂 \\
\hline 64 & 男 & 73 & 糖尿病 & $55 / 08 / 23$ & $55 / 08 / 28$ & $59 / 03 / 14$ & 心 不 全 \\
\hline 65 & 男 & 44 & 慢性系球体腎炎 & $55 / 09 / 06$ & $55 / 10 / 09$ & $56 / 12 / 30$ & 脳血管障害 \\
\hline 66 & 男 & 70 & ネフローゼ症候群 & $55 / 09 / 06$ & $55 / 10 / 14$ & $55 / 12 / 03$ & 肺 出 血 \\
\hline 67 & 男 & 72 & 多発性囊胞粲 & $55 / 10 / 18$ & $55 / 10 / 20$ & $59 / 05 / 30$ & \\
\hline 68 & 男 & 59 & 慢性間質性腎炎 & $55 / 10 / 24$ & $55 / 10 / 24$ & $55 / 11 / 04$ & 心 \\
\hline 71 & 男 & 77 & 糖 尿 病 & & $56 / 02 / 28$ & & \\
\hline 74 & 男 & 66 & 不 明 & $56 / 02 / 23$ & $56 / 04 / 07$ & $56 / 05 / 04$ & 脳血管障害 \\
\hline 77 & 男 & 26 & 慢性系球体腎炎 & $56 / 10 / 12$ & $56 / 10 / 14$ & $58 / 05 / 08$ & 脳血管障害 \\
\hline 80 & 女 & 45 & 糖尿病 & $56 / 11 / 19$ & $56 / 12 / 11$ & $57 / 03 / 22$ & DIC \\
\hline 85 & 男 & 76 & 不 & $56 / 12 / 30$ & $57 / 05 / 04$ & $57 / 05 / 09$ & 心 \\
\hline 86 & 男 & 62 & 糖 & $57 / 05 / 20$ & $57 / 05 / 20$ & $57 / 05 / 26$ & 呼吸停止 \\
\hline 90 & 男 & 69 & 糖 & $57 / 08 / 26$ & $57 / 08 / 26$ & $57 / 09 / 10$ & \\
\hline 95 & 女 & 64 & 不 & $57 / 11 / 04$ & $57 / 11 / 04$ & $60 / 08 / 26$ & \\
\hline 98 & 男 & 58 & アミロイドーシス & $58 / 01 / 27$ & $58 / 01 / 28$ & $59 / 01 / 18$ & 心 \\
\hline 102 & 女 & 63 & 尿病 & $58 / 05 / 02$ & $58 / 05 / 24$ & $59 / 07 / 15$ & \\
\hline 106 & 男 & 57 & 糖 & $58 / 07 / 19$ & $58 / 07 / 25$ & $60 / 01 / 03$ & 心 筋 梗 \\
\hline 107 & 女 & 71 & 糖 & $58 / 07 / 26$ & $58 / 07 / 27$ & $59 / 01 / 30$ & 敗 血 症 \\
\hline 109 & 男 & 63 & 病 & $58 / 10 / 08$ & $58 / 10 / 08$ & $60 / 02 / 13$ & 呼吸不全 \\
\hline 111 & 男 & 54 & 糖尿病 & $58 / 10 / 27$ & $58 / 10 / 27$ & $59 / 10 / 05$ & 心 不 全 \\
\hline 116 & 女 & 46 & 妊 娠 中 毒 症 & $59 / 01 / 13$ & $59 / 01 / 14$ & $59 / 01 / 22$ & 器下性肺炎 \\
\hline 118 & 男 & 70 & 多発 性 露 胞 腎 & $59 / 01 / 24$ & $59 / 01 / 24$ & $60 / 01 / 02$ & \\
\hline 124 & 男 & 69 & 尿 & $59 / 02 / 13$ & $59 / 03 / 07$ & $60 / 01 / 11$ & 消化管出血 \\
\hline
\end{tabular}


Ca $7.8 \pm 1.2 \mathrm{mg} / \mathrm{d} l$ であった. 糖尿病性腎症の患者では心 胸比は $55.6 \pm 7.4 \%$ とやや高く, BUN および $\mathrm{Cr}$ 江各及 $94 \pm 38 \mathrm{mg} / \mathrm{d} l, 8.8 \pm 3.6 \mathrm{mg} / \mathrm{d} l$ と比較的低い值で透析に 導入されている.

退院時の検查成績は収縮期圧 $137 \pm 25 \mathrm{mmHg}$, 拡張期 圧 $81 \pm 17 \mathrm{mmHg}$, 心胸比 $50.1 \pm 6.3 \%$, 赤血球数 $253 \pm$ 56 万, TP $6.6 \pm 0.8 \mathrm{~g} / \mathrm{d} l, \mathrm{BUN} 75 \pm 27 \mathrm{mg} / \mathrm{d} l$, Cr $9.5 \pm 3$. $1 \mathrm{mg} / \mathrm{d} l, \mathrm{Na} 138 \pm 5 \mathrm{mEq} / l, \mathrm{~K} 4.5 \pm 1.0 \mathrm{mEq} / l, \mathrm{Ca} 8.7 \pm$ $1.1 \mathrm{mg} / \mathrm{d} l$ であり, 糖尿病性腎症の患者では $\mathrm{Cr}$ が低值で あった。

6. 導入時のブラッドアクセス（表 6 )

導入時にどのようなブラッドアクセスを用いたかを検 討してみると，内シャントが 47 名 (31.8\%) と約 3 分の 1 を占めて䄺り,続いて大腿静脈穿刺 $\rightarrow$ 内シャント 33 名 $(22.3 \%)$, 外シャント $\rightarrow$ 内ッント 20 名 $(13.5 \%)$, 腹 膜潅流 $\rightarrow$ 内シャント 12 名 (8.1\%) の順番であり，最終 的に内シャントを作製した症例は 148 名中 124 名 (83.8\%)であった。最近の数年間についてみると大腿静 脈留置カテーテルを使用する症例が大多数を占めてい た.

また入院およびブラッドアクセス作製より導入までの 日数についてみると, 表 7 に示したように入院当日に透 析導入した症例が 29 名 (19.7\%)，ブラッドアクセス作 製当日に透析導入した緊急透析症例は 87 名 (59.2\%) に も達していた（他科よりの転科例も含まれている）.

7 . 生存率

昭和 61 年 1 月 1 日現在, 最長の透析施行患者は 63 歳 の女性で慢性透析導入後 13 年 4 力月経過している.

Kaplan-Meier 法で算出した慢性透析導入後の 148 名 の実測生存率を図 1 に示した。 5 年生存率は $56.7 \%, 10$ 年生存率は $46.1 \%$ であった. 特に原疾患が慢性系球体腎 炎と糖尿病の患者の生存率を比較してみると図 2 に示し たように全期間を通して推計学的に有意な差 $(\mathrm{P}<$ 0.001 0.05) が認められ，糖尿病患者の予後が不良であ ることが再認識できた。

\section{8. 死亡症例の検討（表 8)}

昭和 61 年 1 月 1 日現在, 慢性透析導入患者 148 名中 55 名（男性 36 名，女性 19 名）が死亡していた。その死 亡原因の第 1 位は心不全 19 名（うち 5 名は高 $\mathrm{K}$ 血症） (34.5\%)，第 2 位は脳血管障害 12 名 $(21.8 \%)$ ，第 3 位 は感染症 6 名（10.9\%）であった，原疾患別では慢性系 球体腎炎 17 名 (30.9\%), 糖尿病 15 名 $(27.3 \%)$, 多発 性腎囊胞 5 名 (9.1\%), ネフローゼ症候群 4 名 (7.3\%) の順であった。

特に糖尿病性腎症の患者についてみると 21 名（男 16 名，女 5 名）中 15 名（男 12 名，女 3 名）が死亡してお
り，その死亡原因は心不全が 5 名と最も多く，つぎに感 染症が 3 名であり,脳血管障害は 1 名のみと少なかった。

\section{考案}

当科に招ける慢性透析導入患者の男女比は 1.69 ： 1.00 , 導入年齢は $48.4 \pm 16.8$ 歳で 50 歳台が一番多数を 占めていた．単年度であるが全国調査 ${ }^{2}$ によると昭和 60 年透析導入患者では男女比 $1.37: 1.00$, 導入年齢は $54.4 \pm 15.4$ 歳で 50 歳台が最も多く, 類以した点が多 かった.

原疾患についても慢性系球体腎炎が第 1 位，糖尿病が 第 2 位の順番は同じであったが，原疾患不明例の占める 割合は当科導入例で多かった。その理由として当科では 患者の全身状態が悪化した時点で運ばれ，慢性腎不全と 診断し緊急透析を行う症例が多いので原疾患不明例が多 くなったと考元られる. 原疾患の検索・究明が予後とも 関連して今後の課題と思われた。

主訴については疲労感・俋急感が最も多く認められ， 消化器症状は思ったほど多くはなかった，糖尿病性腎症 の患者では浮腫, 呼吸困難等の低蛋白血症と関連すると

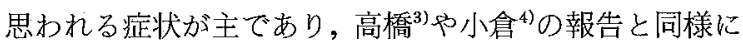
BUN や Cr は平均よりも低い值で透析に導入されてい た。しかしながら成績で述べたように糖尿病性腎症患者 の予後が他の原疾患群よりも極端に悪いことより更に早 期の透析導入，合併症の早期発見が必要と考えられた。 また糖尿病性網膜症や白内障がほぼ全例に認められ失明 例もみられることにより，視力障害の進行防止およびリ ハビリテーションも重要な課題である。

導入時の検查成績について大平ら ${ }^{5)}$ の報告よると血圧 $177 \pm 38 / 99 \pm 19 \mathrm{mmHg}$ ，心胸比 $54.6 \pm 8.1 \%$, Ht $24 \pm$ $6 \%$, TP $6.5 \pm 0.7 \mathrm{~g} / \mathrm{d} l$, BUN $119 \pm 28 \mathrm{mg} / \mathrm{d} l$, Cr $12.7 \pm 4$. $6 \mathrm{mg} / \mathrm{d} l, \mathrm{Na} 137.2 \pm 5.5 \mathrm{mEq} / l, \mathrm{~K} 4.4 \pm 1.1 \mathrm{mEq} / l$ であ り，特に異なる成績はみあたらなかった。

ブラッドアクセスについてみると, 最近の数年間は緊 急透析導入症例に対して大腿静脈留置カテーテルを使用 し，その間に内シャントを作製する方式を主に採用して 表在静脈の温存に努めており，外シャントは特殊な例を 除いてほぼ用いなくなった。最終的に内シャントを用い た症例は $83.8 \%$ であったが, CAPD 導入例も徐々に増え ている.

入院扔よびブラッドアクセス作製より導入までの日数 については，ブラッドアクセス作製当日に透析導入した 緊急透析症例は 87 名で, ブラッドアクセス作製より透析 導入までに 15 日以上の余裕があった患者は 28 名のみで あり，大学病院の性質上，緊急導入が多いためと考えら れる.

慢性透析導入後の 148 名の生存率を調べてみると 5 年 
生存率は $56.7 \%$ あ゙り, 全国調査 ${ }^{2}$ による 5 年生存率 $55.3 \%$ と同じ成績であった。しかし原疾患が慢性系球体 腎炎と糖尿病の患者の生存率を比較した結果，全期間を 通して推計学的に有意な差が認められ，楉尿病腎症患者 の予後が不良であり, 小高ら ${ }^{6)}$ と同様であった. 10 年生存 率は $46.1 \%$ であったが，小高”䛭告した $47.1 \%$ と同様 な成績であった。

慢性透析導入患者 148 名中 55 名が死亡しており，その 死亡原因は心不全，脳血管障害，感染症の順であり，全 国調查 ${ }^{2)}$ にる 1985 年死亡原因分類と全く同じであっ た. 原疾患別では慢性系球体腎炎 17 名, 糖尿病 15 名, 多発性腎囊胞 5 名, ネフローゼ症候群 4 名の順であった。 そのうち特に糖尿病性腎症の患者についてみると 21 名 中 15 名 $(71.4 \%)$ が死亡しており，その死亡原因は鈴木 らの報告 ${ }^{8)}$ と同様に心不全が多かったが脳血管障害は予 想よりも少なかった。また死因として感染症が多いとの 報告8)もる。

\section{結論}

15 年間に慢性透析に導入した患者 148 名について透 析導入時を中心として臨床的な分析を試み，予後につい ても調查した。

その結果当科では透析への緊急導入例が過半数以上を 占めており，慢性腎不全患者の早期発見，早期治療が必 要であり, かつ死亡原因の大半を占める循環器・脳血管 障害の予防も急務であると考えられた，特に原疾患が糖 疗病の患者は他の患者よりも生存率が低く，また導入数
も増加しており透析管理のより一層の工夫・改善が必要 である。

なお本論文の要旨は第 31 回日本透析療法学会において発 表した。

\section{文献}

1）小高通夫, 添田耕司, 小林弘忠, 嶋田俊垣, 佐藤 博 : 人工腎と社会復帰一 13 年間当施設で導入した 519 例の検討と全国統計との比較一。人工蔵器， 14 ： 542-545, 1985.

2）小高通夫：わが国の慢性透析療法の現況 1985 年 12 月 31 日現在. 日本透析療法学会, 1986 .

3）高橋幸夫：糖尿病性腎症の透析療法導入時の合併症 について。透析会誌，14：91-98，1981.

4）小倉三津雄：糖尿病性腎不全患者の導入期につい て. 臨床透析, 1:467-474, 1985.

5）大平整爾, 阿部憲司, 高橋弘昌, 千葉栄市, 菅原剛 太郎：北海道空知地方の透析導入患者の臨床的検 討. 腎と透析, $10 ： 537-541 ， 1981$.

6）小高通夫，添田耕司，嶋田俊垣：糖尿病性腎症の現 況. 臨床透析，1：531-539，1985.

7）小高通夫：透析患者の予後と死因. 日本臨床, 43 (1985 特別号)，481-495，1985.

8）鈴木正司，筒井牧子：循環器合併症に対する対策. 臨床透析, $1: 521-529,1985$. 